ISSN: 2338-8021; E-ISSN: 2338-8269

\title{
MOTIVASI, TERPAAN MEDIA, DAN KEPUASAN KHALAYAK SIARAN RADIO KOMUNITAS JASENG FM, KECAMATAN WALANTAKA, SERANG, BANTEN
}

\section{(Motivation, Media Exposure, and Satisfaction of Jaseng FM Community Radio Audiences, Walantaka District of Serang, Banten)}

\author{
Ditha Fitrialdi Putri ${ }^{1)}$, Hadiyanto ${ }^{1)}$ \\ 1) Departemen Sains Komunikasi dan Pengembangan Masyarakat, Fakultas Ekologi Manusia, \\ Institut Pertanian Bogor, Darmaga Bogor 16680, Indonesia \\ Email: dithafitrialdi@gmail.com; hadi62@apps.ipb.ac.id
}

\begin{abstract}
Audiences are responsible for choosing media especially community radio based on the specific motivations to fulfill desires and needs to achieve satisfaction after listening. This study aimed to know the correlation between demographic characteristics with viewing motivations, the correlation between motivations and quality broadcasting with viewing the media exposure, and the correlation between media exposure with viewing the satisfaction of Jaseng FM community radio listeners. Data were collected using a survey method obtained via questionnaires, direct observation, and in-depth interviews. Respondents are active listeners Jaseng FM radio selected using simple random sampling technique. The results of this study explained that age associated with information motivation and income level associated with personal identity motivation and integration and social interaction motivation. The personal identity motivation associated with duration of listening and selection of broadcast events. The entertainment motivation, integration and social interaction motivation, broadcast material and qualification of broadcaster associated with duration of listening. The media exposure includes duration of listening associated with the surveillance satisfaction and listening frequency associated with personal satisfaction.
\end{abstract}

Keywords: desires, needs, listening, active listeners

\begin{abstract}
ABSTRAK
Khalayak bertanggung jawab untuk memilih media terutama radio komunitas didasarkan pada motivasi khusus untuk memenuhi keinginan dan kebutuhan untuk mencapai kepuasan setelah mendengarkan. Penelitian ini bertujuan untuk mengetahui hubungan karakteristik demografi dengan melihat motivasi, korelasi antara motivasi dan kualitas siaran radio dengan melihat terpaan media, dan korelasi antara terpaan media dengan melihat kepuasan dari pendengar radio komunitas Jaseng FM. Data dikumpulkan dengan menggunakan metode survei yang diperoleh melalui kuesioner, observasi langsung, dan wawancara mendalam. Responden adalah pendengar aktif radio Jaseng FM yang dipilih dengan menggunakan teknik simple random sampling. Hasil penelitian menjelaskan bahwa usia berhubungan dengan motivasi informasi dan tingkat pendapatan yang berhubungan dengan motivasi identitas pribadi dan integrasi dan motivasi interaksi sosial. Motivasi identitas pribadi terkait dengan durasi mendengarkan dan pemilihan peristiwa siaran. Motivasi hiburan, integrasi dan motivasi interaksi sosial, materi siaran dan kualifikasi penyiar terkait dengan durasi mendengarkan. Terpaan media termasuk durasi mendengarkan berhubungan dengan kepuasan pengawasan dan frekuensi mendengarkan berhubungan dengan kepuasan pribadi.
\end{abstract}

Kata kunci: keinginan, kebutuhan, mendengarkan, pendengar aktif 


\section{PENDAHULUAN}

Radio menjadi media penyiaran yang sering digunakan oleh berbagai lapisan masyarakat untuk mendapatkan informasi karena radio dapat mencapai sasarannya secara langsung, mudah, dan tidak mengalami proses yang kompleks. Radio menjadi penyebar informasi pada khalayak yang paling strategis dan memberikan pengaruh pada khalayak khususnya pendengar radio publik seperti Radio Republik Indonesia (RRI).

Radio Republik Indonesia diselenggarakan oleh Lembaga Penyiaran Publik, yaitu lembaga penyiaran yang berbentuk badan hukum yang didirikan oleh negara. Sifat radio publik yang independent, netral, tidak komersial, dan memiliki fungsi dalam memberikan layanan kepada masyarakat, pada kenyataannya belum dirasakan serta masih diabaikan oleh khalayak yang lebih memilih media lain untuk hiburan semata. Wikan (2011) dari SPS (Serikat Perusahaan Pers) dalam seminar literasi media dalam Hendrawati (2013) komposisi pendengar radio setiap tahun semakin menurun, pada tahun 2008 pendengar radio mencapai angka 41,7 \% dan semakin menurun hingga mencapai angka 30,6\% pada tahun 2010. Radio publik belum sepenuhnya berperan dalam memenuhi kebutuhan masyarakat pendengarnya dan lebih digunakan untuk kepentingan pemerintahan, pejabat dan membahas hal-hal umum mengenai pemerintahan. Hal tersebut menjadikan adanya perkembangan baru dan media alternatif untuk radio publik dan radio swasta, yaitu radio komunitas yang diselenggarakan oleh Lembaga Penyiaran Komunitas.

Radio komunitas dikenal secara formal pada tahun 2002 melalui Undang-Undang Penyiaran Nomor 32. Keunggulan media radio yang memiliki jangkauan lebih luas, biaya pengelolaan yang lebih murah, dan kemudahan dalam pengelolaan serta penggunaan teknologi penyiarannya bila dibandingkan dengan media penyiaran televisi, menjadi salah satu alasan mengapa warga pedesaan hingga saat ini masih mengembangkan penyiaran radio berbasis "dari, oleh, untuk dan tentang" warga atau komunitas.

Jaseng FM merupakan salah satu anggota Jaringan Radio Komunitas Indonesia (JRKI) dan satu dari delapan radio komunitas anggota Jaringan Radio Komunitas Banten (JRKB). Jaseng FM didirikan untuk menyebarkan pesan-pesan agama, pendidikan, sosial, budaya, ekonomi, pemerintahan daerah maupun pusat serta berperan serta dalam meningkatkan integritas warga Walantaka Serang.

Pada dasarnya, penggunaan media komunitas, seperti radio komunitas merupakan salah satu cara untuk memperoleh pemenuhan kebutuhan dimana situasi pemuasan kebutuhan akan tercapai dari efek serta penggunaan media tersebut (Rakhmat 2002). Keberlanjutan radio komunitas juga bergantung pada kesetiaan pendengarnya yang selalu mendengarkan serta memberikan masukan mengenai kualitas penyiaran agar radio komunitas berkontribusi dalam mengedepankan pesan lokal dan memenuhi kebutuhan pendengar. Dari hal tersebut menarik untuk dikaji mengenai bagaimana motivasi, kualitas penyiaran radio dan terpaan media dengan kepuasan khalayak siaran radio komunitas Jaseng FM.

Berdasarkan latar belakang tersebut, radio publik belum sepenuhnya mengatasi permasalahan dan memenuhi kebutuhan masyarakat khususnya masyarakat pedesaan. Namun, kenyataannya penyelenggaraan beberapa radio komunitas belum sepenuhnya menjalankan fungsinya sebagai radio komunitas. Tripambudi (2011) menyatakan penelitian di lima radio diantaranya radio Balai Budaya Minomartani Sleman, Radio Cemara Lima Yogyakarta, radio Swara Desa Kulon Progo, Radio Swadiora Kota Bantul dan Radio Informasi Pertanian (Intan) Gunung Kidul belum efektif dalam penyebarluasan informasi lokal yang memang benar-benar dibutuhkan komunitas serta yang menjadi ciri khas komunitas.

Herawati et al. (2005) di radio komunitas Balai Budaya Minomartani FM pengelolaan informasi lokal yang memang benar-benar dibutuhkan komunitas serta yang menjadi ciri khas komunitas telah maksimal dikelola baik secara kualitas radio yaitu teknis, isi, dan manfaat program, namun perhatian masyarakat khususnya intensitas pendengar terhadap program radio tersebut masih kurang maksimal. Intensitas pendengar pada radio ini masih rendah sehingga masyarakat belum merasakan manfaat dari program-program acara radio komunitas tersebut.

Hal ini merupakan permasalahan yang mendasar bagi penyelenggaraan radio komunitas. Radio komunitas berperan sebagai sarana pemberi informasi di tingkat komunitas. Berdasarkan terpaan 
media komunitas diharapkan radio komunitas mampu memenuhi kebutuhan masyarakat pendengar karena saat ini pendengar sangat selektif dalam memilih acara siaran yang sesuai dengan motivasi mereka saat mendengar siaran radio komunitas, namun terpaan media komunikasi seperti radio ini juga memiliki beberapa kelemahan yang berkaitan dengan kualitas siaran. Diperlukan suatu upaya analisis terkait hal-hal yang berhubungan dengan kepuasan pendengar radio komunitas khususnya di radio komunitas Jaseng $\mathrm{FM}$, sehingga dapat dirumuskan pertanyaan penelitian sebagai berikut:

1. Bagaimana hubungan karakteristik demografis pendengar dengan motivasi mendengarkan pendengar radio komunitas Jaseng FM?

2. Bagaimana hubungan motivasi pendengar dengan terpaan radio komunitas Jaseng FM?

3. Bagaimana hubungan kualitas penyiaran dengan terpaan radio komunitas Jaseng FM?

4. Bagaimana hubungan terpaan radio komunitas dengan kepuasan mendengarkan khalayak siaran radio komunitas Jaseng FM?

Berdasarkan rumusan masalah penelitian, maka tujuan penelitian umum pada penelitian ini adalah mengetahui bagaimana pengaruh terpaan radio komunitas terhadap kepuasan khalayak siaran radio komunitas Jaseng FM. Adapun tujuan-tujuan khusus pada penelitian ini adalah sebagai berikut:

1. Menganalisis hubungan karakteristik demografis dengan motivasi mendengarkan pendengar radio komunitas Jaseng FM

2. Menganalisis hubungan motivasi mendengarkan dengan terpaan radio komunitas Jaseng FM

3. Menganalisis hubungan kualitas penyiaran dengan terpaan radio komunitas Jaseng FM

4. Menganalisis hubungan terpaan radio komunitas dengan kepuasan khalayak siaran radio komunitas Jaseng FM.

\section{PENDEKATAN TEORITIS}

\section{Radio Komunitas}

Lembaga penyiaran komunitas di Indonesia berbasiskan "dari, oleh, untuk dan tentang warga atau komunitas", hal tersebut menjadikan lembaga penyiaran komunitas lebih efektif dalam melayani kebutuhan pendengarnya yang mengelola secara langsung lembaga penyiaran tersebut. Lembaga penyiaran komunitas merupakan lembaga penyiaran yang berbentuk badan hukum Indonesia, didirikan oleh komunitas tertentu, bersifat independent dan tidak komersial, dengan daya pancar rendah, luas jangkauan wilayah terbatas, serta untuk melayani kepentingan komunitas (Rachmiatie, 2007). Estrada (2009) dalam Nurmayanti (2011) menyatakan bahwa fungsi radio komunitas antara lain 1) mencerminkan dan mendukung identitas, karakter, dan budaya lokal, 2) menciptakan berbagai pendapat dan opini di udara, 3) mendorong dialog terbuka dan proses demokratis, dan 4) mendukung pembangunan dan perubahan sosial.

Undang-Undang Penyiaran Republik Indonesia No. 32 Tahun 2002 Pasal 21, 22, 23, dan 24 menguraikan bahwa Lembaga Penyiaran Komunitas merupakan lembaga yang berbentuk badan hukum Indonesia, didirikan oleh komunitas tertentu dan memiliki tujuan dalam mendidik dan memajukan masyarakat dalam mencapai kesejahteraan dengan melaksanakan program acara meliputi budaya, pendidikan, dan informasi yang menggambarkan identitas bangsa. Peraturan Pemerintah ini menjadikan landasan bagi penyelenggaraan radio komunitas agar penerapan fungsi serta perannya tetap bermanfaat bagi seluruh pihak yang terlibat serta memperkuat nilai dan mengoptimalkan potensi daerah serta sumberdaya manusia untuk kepentingan nasional.

\section{Karakteristik Pendengar}

Karakteristik khalayak khususnya pendengar radio merupakan faktor utama yang dapat menyebabkan terjadinya suatu aktivitas khalayak dalam mendengarkan radio itu sendiri. Berdasarkan beberapa hasil penelitian, usia, jenis kelamin, tingkat pendidikan dan tingkat pendapatan merupakan faktor karakteristik khalayak yang dapat memengaruhi perilaku mendengar khalayak. Menurut Yani (1998) karakteristik petani dalam mendengarkan siaran radio meliputi usia, jenis kelamin, tingkat pendidikan nonformal, tingkat pendidikan informal, frekuensi ke kota dan frekuensi mengunjungi penyuluh pertanian berhubungan dengan motivasi dan perilaku petani dalam mendengarkan siaran radio $(\mathrm{P}<0,01)$. Pada penelitian ini mayoritas pendengar adalah laki-laki dengan rataan umur 42 tahun, pendapatan keluarga Rp 81.000,00/bulan, pendidikan formal umumnya Sekolah Dasar dan pernah mengikuti kursus atau latihan pertanian.

Patrisia (2011) juga menyatakan bahwa karakteristik usia dan jenis kelamin menjadi faktor yang 
menentukan tempat individu bergabung dalam mempengaruhi proses penerimaan pesan dan bagaimana pesan itu menentukan perilaku seseorang. Faktor tingkat pendidikan akan mempengaruhi minat seseorang terhadap ketertarikannya dengan sebuah berita khususnya informasi yang sesuai dengan kelompok atau komunitasnya, faktor pekerjaan dan pendapatan turut menentukan media apa yang dijadikan dalam memperoleh informasi.

Menurut skala pastisipasi terhadap acara siaran, Masduki (2004) menyatakan terdapat empat jenis pendengar. Salah satunya adalah pendengar aktif yang artinya pendengar yang secara reguler tak terbatas mendengarkan siaran radio dan aktif berinteraksi melalui telepon. Radio menjadi sahabat utama, tidak hanya pada waktu luang.

\section{Motivasi Mendengarkan}

Chaplin (1995) menyatakan pengertian motivasi adalah sebagai satu variabel penyelang (yang ikut campur tangan) yang digunakan untuk menimbulkan faktor-faktor tertentu didalam organisme, yang membangkitkan, mengelola, mempertahankan, dan menyalurkan tingkah laku menuju satu sasaran. Pada pengguna media, motivasi yang dimaksud adalah motivasi untuk memilih suatu media diantara sekian banyak media untuk dijadikan sumber dalam menyalurkan tingkah laku menuju satu sasaran yaitu memperoleh informasi. McQuail (1987) merumuskan motivasi yang mendasari tujuan individu atau khalayak memilih media massa, diantaranya motif informasi, motif identitas pribadi, motif integrasi dan interaksi sosial, dan motif hiburan.

\section{The Uses and Gratifications}

Teori uses and gratifications menentukan bagaimana media memenuhi kebutuhan pribadi dan bukan bagaimana media mengubah sikap dan perilaku khalayak sehingga khalayak aktif yang sengaja menggunakan media untuk mencapai tujuan khusus. Artinya, teori uses and gratifications mengasumsikan bahwa pengguna mempunyai pilihan alternatif untuk memuaskan kebutuhannya (Nurudin, 2007). Terdapat asumsi-asumsi dasar dari teori ini menurut Katz et al. (1974) dalam Baran dan Davis (2000) adalah:

1. Khalayak dianggap aktif, artinya khalayak menggunakan media massa karena memiliki tujuan khusus.
2. Dalam proses komunikasi inisiatif untuk mengaitkan pemuasan kebutuhan dengan pemilihan media tergantung pada kebutuhan.

3. Media massa harus bersaing dengan sumbersumber lain untuk memuaskan kebutuhan khalayak. Bagaimana kebutuhan ini terpenuhi, bergantung kepada perilaku khalayak yang bersangkutan.

4. Tujuan pemilihan media massa berdasarkan kepentingan dan motif-motif tertentu dari khalayak.

5. Penilaian mengenai media massa dilakukan oleh budaya organisasi media massa.

Katz et al. (1973) dalam Effendy (2007) menyatakan terdapat model yang berkembang dari model teori uses and gratifications selain asumsi yang telah dijelaskan sebelumnya. Dalam model tersebut terdapat kepuasan individu atas penggunaan atau fungsi penggunaan media. Kepuasan tersebut tersebut terdiri dari surveillance (pengawasan) yaitu penyediaan informasi tentang lingkungan, kepuasan personal (pribadi) yaitu penguatan nilai atau penambah keyakinan diri misalnya mengidentifikasi diri dengan nilai-nilai dalam media, kepuasan social relationship (hubungan sosial) yaitu untuk menambah peran dan memuaskan konsep dirinya juga untuk berinteraksi dengan orang sekitarnya, serta kepuasan diversion/entertainment (hiburan) yaitu pelarian dari rutinitas dan masalah atau pelepas emosi misalnya untuk mengisi waktu luang dan bersantai.

\section{Terpaan Radio Komunitas dan Kepuasan Khalayak}

Terpaan media Komunitas menurut Shore (1985) dalam Hakim (2010) adalah kegiatan mendengarkan, melihat, membaca pesan media massa ataupun mempunyai pengalaman dan perhatian terhadap pesan tersebut, yang dapat terjadi pada tingkat individu ataupun kelompok. Terpaan media juga dapat didefinisikan sebagai penggunaan media, baik jenis media, frekuensi penggunaan maupun durasi penggunaan (Ardianto dan Erdinaya, 2005).

Pada teori uses and gratification, teori tersebut dirancang untuk menggambarkan proses penerimaan dalam komunikasi massa dan menjelaskan penggunaan media oleh individu atau kelompokkelompok individu. Teori ini mengasumsikan khalayak sebagai khalayak yang aktif dan diarahkan 
oleh tujuan. Anggota khalayak dianggap memiliki tanggung jawabnya sendiri dalam mengadakan pemilihan terhadap media massa untuk mengetahui, memenuhi, dan mengetahui bagaimana cara memenuhi kebutuhannya.

Dalam memperoleh kepuasan dari penggunaan media khususnya radio komunitas, khalayak pendengar memiliki selektifitas yang tinggi serta motivasi untuk memilih suatu media diantara sekian banyak media selain radio. Katz (1974) dalam Morissan (2005) menyatakan bahwa logika yang mendasari teori ini adalah adanya kondisi sosial psikologis seseorang yang menyebabkan adanya kebutuhan yang menciptakan harapan-harapan (motif) terhadap media massa atau sumber-sumber lain yang membawa kepada perbedaan pola penggunaan media. Selanjutnya, akan menghasilkan pemenuhan kebutuhan dan konsekuensi lainnya, termasuk yang tidak diharapkan sebelumnya.

\section{Kualitas Siaran Radio Komunitas}

Untuk mencapai apa yang diinginkan oleh radio penyiaran komunitas dan untuk memperkecil kesenjangan informasi warga serta anggota komunitas pendengar lainnya, kualitas penyiaran radio harus sangat diperhatikan dan menjadi faktor utama keberhasilan radio dalam mencegah kesenjangan informasi.

Penelitian mengenai kualitas siaran radio diantaranya membahas mengenai faktor-faktor yang mempengaruhi kualitas siaran. Faktor-faktor kualitas siaran tersebut diantaranya adalah jenis program siaran, materi siaran, durasi penyiaran, kualitas pemancar radio, dan kualifikasi penyiar. Romli (2009) menyatakan bahwa kelima faktor tersebut merupakan elemen utama dalam menganalisis keunggulan dan kualitas stasiun radio, begitu juga dengan radio komunitas. Jenis program siaran sangat erat hubungannya dengan kesesuaian program siaran dengan visi-misi radio komunitas serta undang undang nomor 32 tahun 2002 tentang penyiaran pasal 21 ayat 2(b), yaitu program acara radio komunitas meliputi budaya, pendidikan dan informasi yang menggambarkan identitas bangsa. Materi siaran dan kualifikasi penyiar radio komunitas sangat berkaitan karena materi siaran yang akan disiarkan oleh penyiar akan tersampaikan secara efektif apabila penyiar radio komunitas berkompeten dan sesuai kualifikasi penyiar seperti: memiliki gagasan luas, sanggup bekerja sama secara kelompok (team work dalam radio komunitas), serta mampu membentuk "mental image" sosok pendengar.

Bisnis siaran radio adalah "bisnis telinga" maka yang berhubungan dengan keindahan dan keberadaan audio hingga sampai ke telinga pendengar harus diperhatikan (Rosalia,2012), oleh karena itu kejernihan pemancar radio juga menjadi salah satu faktor utama yang mempengaruhi kualitas suatu siaran radio. Kenyamanan pendengar dalam mendengarkan suatu siaran sangatlah penting agar pendengar tetap mendengarkan siaran radio khususnya radio komunitas.

\section{Kerangka Pemikiran}

Radio komunitas memiliki khalayak pendengar yang berbeda-beda. Dalam mengetahui kepuasan pendengar radio komunitas Jaseng FM Kota Serang Banten, maka faktor-faktor internal yang ada pada diri individu atau karakteristik demografis pendengar radio komunitas, seperti usia, jenis kelamin, jenis pekerjaan, pendidikan, dan kepemilikan terhadap media massa sangatlah berpengaruh, karena berhubungan dengan motivasi mendengarkan dalam diri pendengar. Motif penggunaan media menurut McQuail (1987) terdiri atas motif informasi, identitas pribadi, integrasi dan interaksi sosial, dan hiburan.

Faktor kualitas penyiaran menentukan frekuensi mendengarkan pendengar seperti halnya variabel terpaan radio komunitas, dimana pendengar akan mendengarkan siaran radio komunitas secara terusmenerus agar pendengar memperoleh kepuasan atas informasi yang mereka butuhkan yang juga disiarkan oleh radio komunitas. Faktor kualitas penyiaran radio tersebut meliputi kesesuaian materi siaran, kualitas penyiar dan kualitas pemancar radio. Karakteristik demografis pendengar berhubungan dengan terpaan radio komunitas yang terjadi pada diri individu yang selanjutnya berhubungan dengan kepuasan individu, kepuasan individu tersebut didasari model uses and gratifications oleh Katz et al. (1973) dalam Effendy (2007) yang terdiri atas kepuasan surveillance (pengawasan), personal (pribadi), social relationship (hubungan sosial), diversion/ entertainment (hiburan). Oleh karena itu, peneliti menganalisis hubungan dari variabel karakteristik demografis pendengar, motivasi pendengar dan kualitas siaran radio komunitas terhadap terpaan radio komunitas dan hubungan 
terpaan media terhadap kepuasan khalayak siaran radio komunitas Jaseng FM Kecamatan Walantaka, Kota Serang, Banten. Berikut kerangka pemikiran yang digunakan pada penelitian ini (Gambar 1).

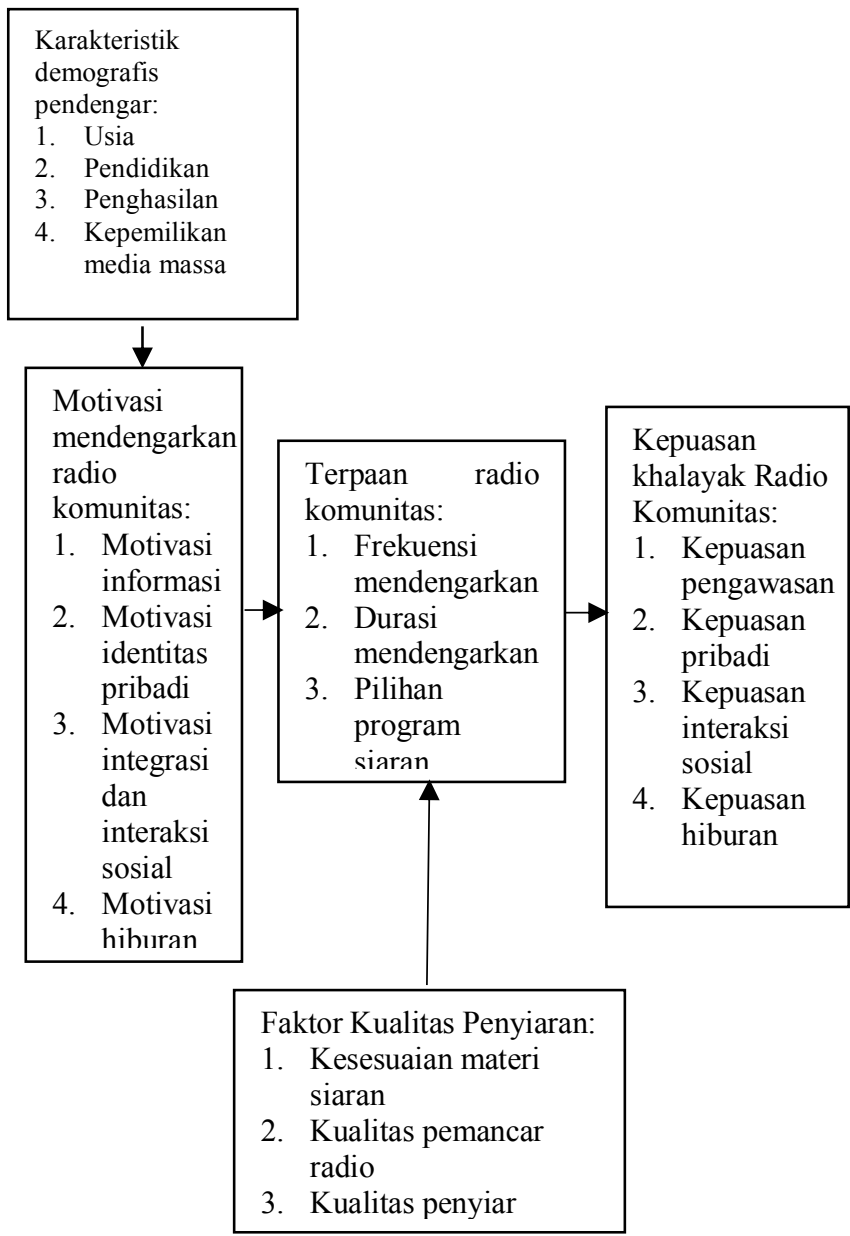

Keterangan :

$\longrightarrow$ : Berhubungan

Gambar 1 Kerangka pemikiran

\section{Hipotesis Penelitian}

Hipotesis penelitian ini disajikan sebagai berikut:

1. Terdapat hubungan antara karakteristik demografis pendengar denganmotivasi mendengarkan radio komunitas Jaseng FM.

2. Terdapat hubungan antara kualitas penyiaran dengan terpaan radio komunitas Jaseng FM.

3. Terdapat hubungan antara motivasi mendengarkan dengan terpaan radio komunitas Jaseng FM.

4. Terdapat hubungan antara terpaan radio komunitas dengan kepuasan mendengarkan khalayak siaran radio komunitas Jaseng FM.

\section{PENDEKATAN LAPANGAN}

\section{Lokasi dan Waktu}

Penelitian ini dilakukan di Radio Komunitas Jaseng FM Jl. KH. Sochari No. 25 Pipitan Walantaka, Serang, Banten. Lokasi ini dipilih secara sengaja (purposive) dengan pertimbangan bahwa radio komunitas ini merupakan stasiun radio komunitas yang telah terdaftar dalam Jaringan Radio Komunitas Banten (JRKB) dan Jaringan Radio Komunitas Indonesia (JRKI). Selain itu, sebagian besar isi siaran dan pengelolaan informasi siaran berdasarkan kebutuhan komunitas atau warga Kecamatan Walantaka, Banten. Wilayah jangkauan siaran radio komunitas adalah $2,5 \mathrm{~km}$ dengan maksimum 50 watt sehingga Desa Pipitan, Desa Walantaka dan Desa Kiara yang menjadi desa lokasi penelitian karena ketiga desa tersebut yang terjangkau oleh sinyal siaran yang dipancarkan radio komunitas Jaseng FM. Waktu penelitian dilaksanakan pada tanggal 15 April 2014 - 27 April 2014. Lokasi dipilih untuk mengetahui bagaimana motivasi, terpaan media, kualitas siaran dan kepuasan khalayak pendengar siaran radio komunitas Jaseng FM.

\section{Jenis Data dan Metode Pengumpulan Data}

Jenis data yang digunakan dalam penelitian ini adalah data primer dan data sekunder. Data primer diperoleh melalui penelitian langsung di lapangan dengan menggunakan instrumen berupa kuesioner. Data primer juga diperoleh dengan melakukan wawancara tidak terstruktur dengan responden untuk menggali pendapat mereka mengenai program siaran radio komunitas. Wawancara juga dilakukan dengan pihak radio komunitas Jaseng FM untuk menggali informasi tentang sejarah, pengelolaan radio komunitas dan program yang disiarkan. Data sekunder diperoleh dari kantor desa mengenai profil desa, data mata pencaharian masyarakat sekitar radio Jaseng FM serta dari pihak Radio komunitas Jaseng FM berupa mengenai profil, sejarah, dan program acara yang disiarkan radio komunitas.

\section{Teknik Pengolahan dan Analisis Data}

Data yang diperoleh dianalisis secara kuantitatif dengan menggunakan kuesioner. Data yang terkumpul dianalisis dengan uji Statistik Rank Spearman menggunakan Statistic Program for Social Sciences (SPSS) for Windows versi 16.0 dan Microsoft Excel 2007. Keeratan hubungan antara dua variabel dapat diketahui dengan 
menggunakankoefisien kontingensi (Singarimbun dan Effendi, 2008). Derajat hubungan yang meliputi kekuatan hubungan dan bentuk/arah hubungan dapat diketahui menggunakan Koefisien Korelasi (KK). Analisis data kualitatif tidak menggunakan model matematik, hanya terbatas pada metode reduksi data, yaitu pemilihan data, pemusatan perhatian, dan penyederhanaan data, lalu penyajian data secara deskriptif dan dilanjutkan penarikan kesimpulan.

\section{GAMBARAN UMUM RADIO KOMUNITAS JASENG FM}

Pada tahun 2007 sesuai dengan Undang-Undang Negara Republik Indonesia nomor 32 tahun 2007 tentang pembentukan kota Serang, Kecamatan Walantaka mengalami perubahan sehingga Kecamatan Walantaka menjadi salah satu dari enam Kecamatan yang berada di wilayah Kota Serang. Kecamatan yang didominasi oleh lahan padi dan palawija ini, memiliki luas wilayah seluas 41.01 $\mathrm{km}^{2}$. Kecamatan yang memiliki kepadatan penduduk sebesar $1845 \mathrm{~km}^{2}$ ini memiliki tingkat kerukunan yang sangat baik, sehingga potensi konflik di daerah ini sangat rendah.

Jumlah penduduk Kecamatan Walantakaper-tahun 2010 adalah 75.681 jiwa dengan perincian 38.580 laki-laki dan 37.101 perempuan. Terdapat 14 desa dengan jumlah penduduk tersebar dalam 59 Rukun Warga (RW) dan 231 Rukun Tetangga (RT). Tingkat pendidikan masyarakat Walantaka juga tergolong cukup baik karena rata-rata masyarakat telah menempuh pendidikan hingga Sekolah Dasar maupun Madrasah Ibtidaiyah dengan persentase sebesar 40.11 persen.

Tingkat kesehatan masyarakat Kecamatan Walantaka tergolong cukup baik karena terdapat sarana kesehatan seperti puskesmas, puskesmas pembantu, poliklinik, dan terdapat 101 unit posyandu di Kecamatan ini, walaupun terdapat penduduk kategori rumah tangga miskin sebanyak 2624 jiwa.

\section{Sejaran Radio Komunitas Jaseng FM}

Different Quality (DQ) FM Radio 96,3 FM merupakan nama pertama radio komunitas di Kecamatan Walantaka yang digagas oleh bapak Amrullah selaku pendiri radio komunitas Jaseng FM. Berawal pada tahun 1995, beliau merakit sendiri pemancar radio untuk radio ini namun makna radio gelap saat itu adalah sebagai landasan berdirinya DQ Radio. Pada saat itu Kartu Atensi atau Kartu Pilihan Pendengar (pilpen) sebagai telah diminati oleh para pendengar sehingga pemasukan radio hampir mencapai $\mathrm{Rp} 120.000,00$ - Rp. $150.000,00$ /hari. Kartu tersebut berisi Nama, Alamat, Permintaan lagu atau request serta salamsalam pendengar. Berdasarkan Pasal 7 ayat (3) Undang-Undang Nomor 32 Tahun 2002 tentang penyiaran, untuk kelancaran efisiensi dan optimalisasi pelaksanaan tugas Komisi Penyiaran Indonesia Daerah, perlu didukung kesekretariatan Komisi Penyiaran Indonesia Daerah banten ${ }^{1}$. Hal tersebut mendorong pengelola dalam pembentukan Komisi Penyiaran Indonesia Daerah (KPID) Banten dan Jaringan Radio Komunitas Banten (JRKB) hingga pada tahun 2006 menjadikan DQ FM berubah nama menjadi RAM FM atau Radio Komunitas Al-Mutaffail. Hal tersebut karena adanya akte notaris dan legalitas radio komunitas, sehingga radio komunitas membutuhkan yayasan sebagai payung hukum dan terbentuk RAM FM.

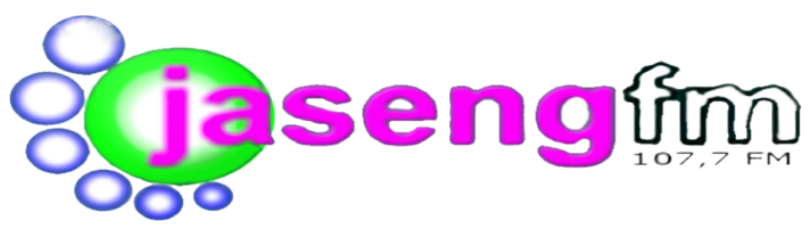

Gambar 2 Logo radio komunitas Jaseng FM

Seiring berjalannya waktu dan setelah legalitas pendirian radio komunitas tersebut didapatkan, terdapat beberapa hambatan yang dialami radio komunitas ini. Sebagian aset radio dijual untuk kepentingan tertentu. Hal tersebut tidak menjadi hambatan bagi Amrullah dan teman-teman pengelola lainnya, sehingga pada tahun 2006 didirikanlah kembali radio komunitas. Adanya regulasi baru mengenai penyiaran maka radio komunitas ini memasuki kanal frekuensi penyiaran komunitas khususnya radio komunitas dengan frekuensi 107,7 $\mathrm{FM}^{2}$. Namun, terdapat radio komunitas lain di frekuensi 107 FM yang jaraknya sangat berdekatan. Berdasarkan aturan radio komunitas $^{3}$ maka kedua radio tersebut harus

\footnotetext{
${ }^{1}$ Peraturan Daerah Provinsi Banten Nomor 2 Tahun 2009 Tentang Pembentukan Sekretariat Komisi Penyiaran Indonesia Daerah Provinsi

${ }^{2}$ Peraturan Menteri Komunikasi dan Informatika Nomor 13/PER/M.KOMINFO/08/2010 Tentang Perubahan Kedua Atas Keputusan Menteri Perhubungan Nomor: KM 15 Tahun 2003 Tentang Rencana Induk (Master Plan) Untuk Keperluan Radio Siaran FM (Frequency Modulation)

${ }^{3}$ Undang-Undang Republik Indonesia Nomor 32 Tahun 2002 tentang Penyiaran
} 
disatukan, sehingga adanya peremajaan pemancar, penghidupan kembali radio, dan pengambilan nama baru yaitu Jaseng FM sebagai nama baru dari penggabungan kedua radio tersebut.

Bulatan besar berwarna hijau dan enam bulatan kecil dengan beragam ukuran di samping nama Jaseng FM Logo radio komunitas menunjukkan walaupun terdapat beragam keyakinan akan tetap terjalin kebersamaan yang disatukan oleh media yang dicerminkan dengan satu bulatan besar yaitu Jaseng FM. Radio ini adalah media untuk pemersatu hubungan masyarakat Serang khususnya Kecamatan Walantaka. Warna hijau mencerminkan gerakan dan warna merah muda pada nama Jaseng mencerminkan keberanian anak-anak muda pendiri Jaseng FM sehingga kedua warna tersebut mencerminkan bahwa Jaseng FM sebagai gerakan anak-anak muda yang pemberani.

\section{Program siaran radio komunitas Jaseng FM}

Program yang disiarkan oleh radio komunitas Jaseng FM ini sesuai dengan undang-undang penyiaran nomor 32 tahun 2002 pasal 20 ayat 2(b) yaitu program lembaga penyiaran komunitas ditujukan untuk mendidik dan memajukan masyarakat dalam mencapai kesejahteraan dengan melaksanakan program acara yang meliputi budaya, pendidikan, dan informasi yang menggambarkan identitas bangsa. Format siaran radio Jaseng FM adalah multi contemperory (pendengar dari kalangan remaja, muda dan dewasa) yang dibedakan dalam empat kategori format acara, yaitu ${ }^{4}$ 1) program acara yang memiliki kontribusi terhadap pemahaman, pengetahuan bersifat pendidikan, budaya dan agama, 2) program acara yang memiliki kontribusi berita informasi, 3) program acara hiburan dan kesenian, dan 4) program acara yang memiliki Iklan Layanan masyarakat.

Susunan program dan jam siaran diusun oleh pengelola dan mengalami beberapa perubahan seiring dengan berkembangnya sumber daya manusia (SDM) pengelola radio komunitas dan berkembangnya teknologi penyiaran. Radio komunitas merupakan radio "untuk warga oleh warga dari warga dan tentang warga", sehingga radio komunitas dijadikan sebagai fasilitas warga dan mitra pemerintahan pusat, pemerintahan daerah,

\footnotetext{
${ }^{4}$ Undang-Undang Republik Indonesia Nomor 32 Tahun 2002 tentang Penyiaran

${ }^{5} \mathrm{http}: / /$ jasengfm.blogspot.com
}

dan lembaga-lembaga sosial dalam upaya pembangunan sosial khususnya di Kecamatan Walantaka.

Sosialisasi program dari beberapa lembaga berlangsung pada saat program acara talkshow atau bincang-bincang dengan narasumber yang bersangkutan dengan tema talkshow dan melalui iklan layanan masyarakat. Format program siaran berupa talkshow tersebut disisipkan di beberapa program siaran yang telah disusun oleh pengelola radio komunitas. Hal ini disesuaikan dengan narasumber dan hanya menyajikan acara yang sifatnya menghibur, radio komunitas tetap menyisipkan informasi yang sifatnya membangun kualitas SDM pendengar radio komunitas Jaseng FM. Iklan layanan masyarakat bertujuan untuk meyakinkan masyarakat akan program tersebut dengan cara yang lebih menghibur dan menarik minat para pendengar.

\section{Pengelolaan dan pembiayaan radio komunitas Jaseng FM}

Pengelolaan radio komunitas tidak serumit radio komersil maupun radio publik karena pada dasarnya radio komunitas dikelola oleh komunitas atau warga Kecamatan Walantaka. Pembiayaan untuk mengelola radio komunitas pada awal penyiaran menggunakan kartu atensi atau kartu pilihan pendengar (pilpen), namun kartu atensi tidak berlanjut karena perkembangan zaman dan teknologi dan pendengar saat ini bisa berkirim salam menggunakan telepon dan $S M S$ ke radio Jaseng FM. Walaupun dikelola sendiri oleh warga, radio komunitas ini memiliki beberapa penyiar yang datangnya dari luar Kecamatan Walantaka, namun tidak menganggu penyiaran radio komunitas karena radio komunitas Jaseng FM sangat menerima antusiasme warga dari luar Kecamatan Walantaka untuk menjadi penyiar. Penyiar juga harus tetap menaati peraturan yang berlaku dan bersiaran sesuai dengan visi dan misi radio Jaseng FM.

Penyiar radio komunitas Jaseng FM mayoritas adalah laki-laki. Para penyiar wanita yang pernah menjadi penyiar tetap di radio ini sudah mengundurkan diri. Tidak memerlukan keahlian khusus bagi warga yang ingin menjadi penyiar di radio komunitas ini, karena pengelola sangat terbuka dengan siapa saja yang ingin siaran. Beberapa sekolah di Kota Serang juga sering berkunjung dan menggunakan radio komunitas ini sebagai bahan pelatihan murid-murid sekolah baik 
di tingkat SMP, SMA hingga Universitas dalam memahami bagaimana jurnalistik penyiaran radio.

\section{HASIL DAN PEMBAHASAN}

\section{Karakteristik Demografis Pendengar}

Karakteristik Demografis pendengar merupakan salah satu faktor yang dapat menjelaskan perbedaan setiap responden yang dapat mempengaruhi bagaimana responden terdedah terhadap media khususnya adalah radio komunitas Jaseng FM. Tabel 1 menunjukkan jumlah dan persentase responden berdasarkan karakteristik demografis pendengar.

Tabel 1 Jumlah dan persentase responden berdasarkan karakteristik demografis pendengar di Kecamatan Walantaka Tahun 2014

\begin{tabular}{|c|c|c|c|}
\hline No & Karakteristik demografis & $\begin{array}{l}\text { Jumlah } \\
\text { (orang) }\end{array}$ & $\begin{array}{l}\text { Persen } \\
(\%)\end{array}$ \\
\hline \multirow[t]{4}{*}{1} & Usia & & \\
\hline & $\begin{array}{l}\text { Masa awal dewasa } \\
\text { (18-29 tahun) }\end{array}$ & 20 & 66.67 \\
\hline & $\begin{array}{l}\text { Masa usia menengah } \\
\text { (30-50 tahun) }\end{array}$ & 7 & 23.33 \\
\hline & $\begin{array}{l}\text { Masa tua } \\
(>50 \text { tahun })\end{array}$ & 3 & 10.00 \\
\hline \multirow[t]{3}{*}{2} & Jenis Kelamin & & \\
\hline & Laki-laki & 21 & 70.00 \\
\hline & Perempuan & 9 & 30.00 \\
\hline \multirow[t]{6}{*}{3} & Tingkat pendapatan & & \\
\hline & $\begin{array}{l}\text { Rendah } \\
(<\text { Rp 100.000,00/ bulan) }\end{array}$ & 14 & 46.67 \\
\hline & $\begin{array}{l}\text { Sedang } \\
\geq \operatorname{Rp} 100.000,00-\end{array}$ & & \\
\hline & Rp 1.000.000,00/ bulan) & 6 & 20.00 \\
\hline & Tinggi & & \\
\hline & $(>\operatorname{Rp} 1.000 .000,00)$ & 10 & 33.33 \\
\hline \multirow[t]{4}{*}{4} & Tingkat pendidikan & & \\
\hline & Rendah (SD) & 1 & \\
\hline & $\begin{array}{l}\text { Sedang } \\
\text { (SMP-SMA) }\end{array}$ & 21 & $\begin{array}{r}3.33 \\
70.00\end{array}$ \\
\hline & Tinggi (Perguruan Tinggi) & 8 & 26.67 \\
\hline \multirow[t]{6}{*}{5} & Kepemilikan media massa & & \\
\hline & $\begin{array}{l}\text { Rendah (memiliki satu dari } \\
\text { ketiga media massa (koran, } \\
\text { radio dan televisi) }\end{array}$ & 9 & 30.00 \\
\hline & Sedang (memiliki dua dari & & \\
\hline & ketiga media massa & 15 & 50.00 \\
\hline & $\begin{array}{l}\text { Tinggi (memiliki ketiga media } \\
\text { massa) }\end{array}$ & 6 & 20.00 \\
\hline & Total & 30 & 100.00 \\
\hline
\end{tabular}

Motivasi Mendengarkan Radio Komunitas JASENG FM

Motivasi penggunaan media menurut McQuail (1987) terdiri atas motivasi informasi, identitas pribadi, integrasi dan interaksi sosial, dan hiburan. Pada penelitian ini motivasi tertinggi pada motivasi informasi dengan kategori motivasi informasi tinggi, yaitu sebesar 90.00 persen. Pendengar memilki motivasi untuk mengetahui informasi mengenai komunitasnya dan keadaan wilayah Kota Serang dan sekitar Kecamatan Walantaka. Selain itu, motivasi lain yang dipilih pendengar adalah motivasi hiburan dengan persentase sebesar 70.00 persen yang menjadikan radio sebagai media dalam mengisi waktu luang.

Tabel 2 Jumlah dan persentase responden berdasarkan motivasi mendengarkan siaran radio komunitas Jaseng FM di Kecamatan Walantaka Tahun 2014

\begin{tabular}{|c|c|c|c|}
\hline No & Jenis motivasi & $\begin{array}{l}\text { Jumlah } \\
\text { (orang) }\end{array}$ & $\begin{array}{c}\text { Persen } \\
(\%)\end{array}$ \\
\hline \multirow{4}{*}{1} & Motivasi informasi & & \\
\hline & Rendah & 0 & 0.00 \\
\hline & Sedang & 3 & 10.00 \\
\hline & Tinggi & 27 & 90.00 \\
\hline \multirow{5}{*}{2} & Motivasi & & \\
\hline & Pribadi & & \\
\hline & Rendah & 4 & 1333 \\
\hline & Sedang & 17 & 5667 \\
\hline & Tinggi & $\begin{array}{r}17 \\
9\end{array}$ & $\begin{array}{l}56.6 / \\
30.00\end{array}$ \\
\hline \multirow{4}{*}{3} & $\begin{array}{l}\text { Motivasi integrasi dan } \\
\text { interaksi sosial }\end{array}$ & & \\
\hline & Rendah & 2 & 6.66 \\
\hline & Sedang & 14 & 46.67 \\
\hline & Tinggi & 14 & 46.67 \\
\hline \multirow{5}{*}{4} & Motivasi hiburan & & \\
\hline & Rendah & 1 & 3.33 \\
\hline & Sedang & 21 & 70.00 \\
\hline & Tinggi & 8 & 26.67 \\
\hline & Total & 30 & 100.00 \\
\hline
\end{tabular}

\section{Kualitas Penyiaran Radio Komunitas Jaseng FM}

Romli (2009) menyatakan bahwa jenis program siaran, materi siaran, durasi penyiaran, kualitas pemancar radio, dan kualifikasi penyiar merupakan elemen utama dalam menganalisis keunggulan dan kualitas stasiun radio, begitu juga dengan radio komunitas. Kualitas penyiaran radio komunitas tergolong cukup baik karena pendengar dengan mudahnya mencari frekuensi radio komunitas Jaseng FM yaitu 107,7 FM.

Pada kualitas penyiaran, persentase tertinggi terdapat pada penilaian responden terhadap kesesuaian materi siaran, yaitu sebesar 66.67 persen. Materi yang disiarkan sudah sesuai dengan visi dan misi radio komunitas Jaseng FM serta sesuai dengan 
budaya, nilai dan norma. Didukung dengan kemampuan para penyiar Jaseng FM yang mahir dalam membawakan program siaran Jaseng FM sehingga kualitas penyiar termasuk dalam kategori sedang dengan persentase sebesar 53.33 persen dan kategori tinggi dengan persentase sebesar 46.67 persen. Namun, kualitas pemancar masih termasuk dalam kategori rendah karena terkadang pendengar tidak secara jernih dapat mendengarkan siaran radio komunitas Jaseng FM saat cuaca mulai memburuk.

Tabel 3 Jumlah dan persentase responden berdasarkan kualitas penyiaran radio komunitas Jaseng FM di Kecamatan Walantaka Tahun 2014

\begin{tabular}{|c|c|c|c|}
\hline No & Kualitas penyiaran & $\begin{array}{l}\text { Jumlah } \\
\text { (orang) }\end{array}$ & $\begin{array}{c}\text { Persen } \\
(\%)\end{array}$ \\
\hline \multirow{4}{*}{1} & Kesesuaian materi siaran & & \\
\hline & Kesesuaian rendah & 3 & 10.00 \\
\hline & Kesesuaian sedang & 20 & 66.67 \\
\hline & Kesesuaian tinggi & 7 & 23.33 \\
\hline \multirow{5}{*}{2} & Kualitas pemancar radio & & \\
\hline & Kualitas pemancar rendah & 12 & 40.00 \\
\hline & Kualitas pemancar sedang & & \\
\hline & Kualitas pemancar tinggi & 7 & 23.33 \\
\hline & & 11 & 36.67 \\
\hline \multirow{5}{*}{3} & Kualitas penyiar & & \\
\hline & Kualitas penyiar rendah & 0 & 0.00 \\
\hline & Kualitas penyiar sedang & 16 & 53.33 \\
\hline & Kualitas penyiar tinggi & 14 & 46.67 \\
\hline & Total & 30 & 100.00 \\
\hline
\end{tabular}

\section{Terpaan Media Radio Komunitas JASENG FM}

Katz (1974) dalam Morissan (2005) menyatakan bahwa kondisi sosial psikologis seseorang menyebabkan adanya kebutuhan yang menciptakan harapan-harapan (motif) terhadap media massa atau sumber-sumber lain yang membawa kepada perbedaan pola penggunaan media. Selanjutnya perbedaan pola pengunaan media ini akan menghasilkan pemenuhan kebutuhan dan konsekuensi lainnya, termasuk yang tidak diharapkan sebelumnya. Penggunaan media pada penelitian ini meliputi terpaan pendengar terhadap radio komunitas Jaseng FM yaitu frekuensi mendengarkan, durasi mendengarkan dan pemilihan acara siaran Jaseng FM. Frekuensi mendengarkan merupakan seberapa sering dalam hitungan hari dalam satu minggu responden mendengarkan radio komunitas, sedangkan durasi mendengarkan adalah seberapa sering dalam hitungan menit dalam satu hari responden mendengarkan radio komunitas. Pemilihan acara siaran merupakan banyaknya acara yang didengarkan responden pada saat satu hari sebelum peneliti memberikan kuesioner kepada responden khususnya para pendengar aktif radio komunitas Jaseng FM. Penemuan peneliti di lapang bahwa frekuensi mendengarkan pendengar aktif radio Jaseng FM memiliki persentase tertinggi pada kategori sedang yaitu mendengarkan radio dalam tiga sampai empat hari dalam satu minggu.

Tabel 4 Jumlah dan persentase responden berdasarkan terpaan media radio komunitas Jaseng FM di Kecamatan Walantaka tahun 2014

\begin{tabular}{|c|c|c|c|}
\hline No & Terpaan media & $\begin{array}{l}\text { Jumlah } \\
\text { (orang) }\end{array}$ & $\begin{array}{c}\text { Persen } \\
(\%)\end{array}$ \\
\hline \multirow{4}{*}{1} & $\begin{array}{l}\text { Frekuensi mendengarkan (dalam } \\
\text { seminggu) }\end{array}$ & & \\
\hline & Rendah ( $1-2$ hari) & 1 & 3.33 \\
\hline & Sedang ( $3-4$ hari) & 23 & 76.67 \\
\hline & Tinggi ( $\geq 5$ hari) & 6 & 20.00 \\
\hline \multirow{4}{*}{2} & $\begin{array}{l}\text { Durasi mendengarkan (dalam } \\
\text { menit) }\end{array}$ & & \\
\hline & Rendah ( $<180$ menit $)$ & 22 & 73.33 \\
\hline & Sedang ( $\geq 180-240$ menit) & 6 & 20.00 \\
\hline & Tinggi (>240menit) & 2 & 6.67 \\
\hline \multirow{5}{*}{3} & Pemilihan acara & & \\
\hline & Rendah (1 acara) & 20 & 66.67 \\
\hline & Sedang (2 acara) & 9 & 30.00 \\
\hline & Tinggi ( $3-4$ acara) & 1 & 3.33 \\
\hline & Total & 30 & 100.00 \\
\hline
\end{tabular}

Pada durasi mendengarkan persentase tertinggi terdapat pada kategori rendah dengan durasi kurang dari 180 menit dalam satu hari. Hal tersebut sesuai dengan pilihan acara responden yang termasuk dalam kategori rendah, yaitu hanya memilih satu dari empat acara yang ada. Satu acara atau program siaran Jaseng FM memiliki durasi 3-4 jam atau dalam hitungan menit adalah 180 menit atau bisa lebih di hari-hari atau tema tertentu, sehingga persentase tertinggi termasuk pada durasi dan pemilihan acara kategori rendah.

\section{Hubungan Karakteristik Demografis dengan Motivasi Mendengarkan Radio Komunitas JASENG FM}

Tabel 5 menunjukkan bahwa semakin tua usia pendengar aktif radio komunitas maka semakin rendah motivasi pribadi, motivasi integrasi dan interaksi sosial dan motivasi hiburannya. Hasil uji rank spearman menyatakan usia hanya berhubungan nyata dengan motivasi informasi $(\mathrm{p}<0.05)$. Responden yang memiliki usia lebih tua lebih memilih untuk berinteraksi secara langsung dan tidak menggunakan media dalam kehidupan sehari- 
harinya, namun hanya ingin mendengarkan informasi yang sifatnya menambah pengetahuan mengenai daerah sekitar dan hal-hal yang sifatnya aktual melalui media radio komunitas Jaseng FM.

Tabel 5 Hasil uji statistik korelasi antara karakteristik demografis pendengar dengan motivasi mendengarkan radio komunitas Jaseng FM di Kecamatan Walantaka tahun 2014

\begin{tabular}{llcccc}
\hline & & \multicolumn{4}{c}{ Jenis motivasi } \\
\cline { 3 - 6 } No & $\begin{array}{l}\text { Karakteristik } \\
\text { demografis }\end{array}$ & $\begin{array}{c}\text { Motivasi } \\
\text { informasi }\end{array}$ & $\begin{array}{c}\text { Motivasi } \\
\text { identitas } \\
\text { pribadi }\end{array}$ & $\begin{array}{c}\text { Motivasi } \\
\text { integrasi } \\
\text { danteraksi } \\
\text { sosial }\end{array}$ & $\begin{array}{c}\text { Motivasi } \\
\text { hiburan }\end{array}$ \\
\hline 1 & Usia & 0.009 & -0.558 & -0.623 & -0.195 \\
2 & $\begin{array}{l}\text { Jenis } \\
\text { kelamin }\end{array}$ & 0.894 & 0.072 & 0.075 & 0.551 \\
\hline & $\begin{array}{l}\text { Tingkat } \\
\text { pendidikan } \\
\text { Tingkat } \\
\text { pendapatan }\end{array}$ & 0.275 & -0.517 & -0.668 & -0.595 \\
\hline $\begin{array}{l}\text { Kepemilik- } \\
\text { an media } \\
\text { massa }\end{array}$ & $0.029 *$ & $0.004 *$ & $0.019 *$ & 0.098 \\
\hline
\end{tabular}

Keterangan:

* = Correlation is significant at the 0.05 level (2-tailed)

Tingkat pendapatan berhubungan nyata dengan motivasi informasi, motivasi identitas pribadi, dan motivasi integrasi dan interaksi sosial karena golongan pendengar memiliki waktu luang yang lebih untuk mendengarkan radio komunitas sehingga motivasi mendengarkan juga tinggi, baik dalam mencari informasi maupun sekedar berinteraksi dengan pendengar lain. Khalayak lebih memilih radio untuk mendapatkan informasi dan hiburan khususnya radio komunitas karena radio bertenaga listrik maupun baterai dan menggunakan aplikasi radio di telepon genggam bertujuan untuk menghemat pengeluaran karena penggunaan media lain, seperti televisi akan lebih mahal dan memberatkan pengeluaran setiap bulannya.

Pada jenis kelamin, tingkat pendidikan, dan kepemilikan media massa tidak terdapat hubungan nyata dengan motivasi mendengarkan karena radio komunitas berprinsip "dari-oleh-untuk-tentang warga atau komunitas" maka tanpa memiliki media radio secara khusus dan lulusan dari tingkat pendidikan dapat mendengarkan dan berpartisipasi.

\section{Hubungan Kualitas Penyiaran dengan Terpaan Media Radio Komunitas JASENG FM}

Hubungan yang terjadi antara kualitas penyiaran yang terdiri dari kualitas penyiar dan kesesuaian materi siaran dengan terpaan media menunjukkan hubungan nyata pada aspek durasi penyiaran $(p<0.05)$. Semakin lama pendengar mendengar siaran radio komunitas dalam satu hari, maka penyiar merasakan bagaimana kualitas penyiaran radio Jaseng FM begitupula dengan kualitas penyiar dan kesesuaian materi siaran dengan program dan visi serta misi radio komunitas Jaseng FM. Hasil wawancara mendalam dengan responden menunjukkan bahwa semakin lama mendengarkan radio bila materi yang disiarkan sesuai atau mengenai komunitasnya. Hubungan yang cukup berarti antara kualitas penyiar dengan durasi mendengarkan ditunjukkan dengan semakin baik, menarik, komunikatif penyiar dalam membawakan acara siaran, maka pendengar lebih lama mendengarkan radio komunitas Jaseng FM.

Tabel 6 Hasil uji statistik korelasi antara kualitas penyiaran dengan terpaan media radio komunitas Jaseng FM di Kecamatan Walantaka tahun 2014

\begin{tabular}{llccc}
\hline \multirow{2}{*}{ No } & $\begin{array}{l}\text { Kualitas } \\
\text { penyiaran }\end{array}$ & $\begin{array}{c}\text { Frekuensi } \\
\text { mendengar- } \\
\text { kan }\end{array}$ & $\begin{array}{c}\text { Durasi } \\
\text { mendengar- } \\
\text { kan }\end{array}$ & $\begin{array}{l}\text { Pemilih- } \\
\text { an acara } \\
\text { siaran }\end{array}$ \\
\hline 1 & $\begin{array}{l}\text { Kesesuaianmateri } \\
\text { siaran }\end{array}$ & 0.131 & $0.017^{*}$ & -0.215 \\
2 & $\begin{array}{l}\text { Kualitas } \\
\text { pemancar }\end{array}$ & 0.315 & 0.066 & -0.366 \\
3 & Kualitas penyiar & 0.762 & $0.005^{*}$ & -0.055 \\
\hline
\end{tabular}

Hubungan Motivasi Mendengarkan dengan Terpaan Media Radio Komunitas JASENG FM

Motivasi mendengarkan radio komunitas Jaseng FM berhubungan dengan terpaan media. Hubungan tersebut terjadi pada motivasi identitas pribadi, motivasi integrasi dan interaksi sosial, dan motivasi hiburan dengan durasi mendengarkan radio komunitas $(\mathrm{p}<0.01)$. Hasil uji statistik Rank Spearman tidak menunjukkan hubungan antara motivasi informasi dengan terpaan media, karena tingginya motivasi informasi pendengar tidak mempengaruhi seberapa sering dan seberapa lama mendengarkan radio komunitas. Selain itu, terdapat hubungan nyata antara motivasi identitas pribadi dengan pemilihan acara karena dalam mendengarkan radio, pendengar akan memilih lebih dari satu acara untuk menjadikan dirinya lebih dikenal dan mengetahui banyak hal setelah mendengarkan beberapa program siaran radio komunitas. Hasil wawancara mendalam dengan responden menunjukkan bahwa semakin lama pendengar mendengarkan siaran radio komunitas 
serta semakin banyak acara yang didengarkan, maka mereka akan terlihat sebagai pendengar aktif radio komunitas Jaseng FM dan lebih dikenal pendengar aktif lainnya yang sering menelepon maupun berkirim salam melalui $S M S$.

Tabel 7 Hasil uji statistik korelasi antara motivasi mendengarkan dengan terpaan media radio komunitas Jaseng FM di Kecamatan Walantaka tahun 2014

\begin{tabular}{llccc}
\hline & \multicolumn{3}{c}{ Motivasi } \\
No & $\begin{array}{c}\text { mendengar- } \\
\text { kan }\end{array}$ & $\begin{array}{c}\text { Frekuensi } \\
\text { mendengar- } \\
\text { kan }\end{array}$ & $\begin{array}{c}\text { Durasi } \\
\text { mendengar- } \\
\text { kan }\end{array}$ & $\begin{array}{c}\text { Pemilih } \\
\text {-an acara } \\
\text { siaran }\end{array}$ \\
\hline 1 & $\begin{array}{l}\text { Motivasi } \\
\text { informasi }\end{array}$ & 0.714 & -0.156 & -0.246 \\
2 & $\begin{array}{l}\text { Motivasi } \\
\text { identitas } \\
\text { pribadi } \\
\text { Motivasi } \\
\text { integrasi dan } \\
\text { interaksi } \\
\text { sosial } \\
\text { Motivasi } \\
\text { hiburan }\end{array}$ & 0.377 & $0.000^{* *}$ & $0.007^{* *}$ \\
\hline
\end{tabular}

Keterangan:

$* *=$ Correlation is significant at the 0.01 level (2-tailed)

Hubungan Terpaan Media dengan Kepuasan Mendengarkan Radio Komunitas Jaseng FM

Model yang berkembang dari Katz et al. (1973) yaitu model teori uses and gratifications menjelaskan empat tipe kepuasan yaitu surveillance (pengawasan), personal (pribadi), social relationship (hubungan sosial), dan entertainment (hiburan). Tabel 8 memperlihatkan jumlah responden berdasarkan kepuasan mendengarkan dan kategori kepuasan mendengarkan. Pada tabel ini memperlihatkan jumlah responden berdasarkan kepuasan mendengarkan yang menunjukkan bahwa persentase tertinggi terdapat pada kepuasan pengawasan dan kepuasan interaksi sosial dengan persentase sebesar 70.00 persen. Kepuasan dirasakan pendengar setelah mendengarkan siaran radio komunitas Jaseng FM.

Terpaan media radio komunitas Jaseng FM berhubungan nyata dengan kepuasan mendengarkan. Hubungan tersebut terjadi antara frekuensi mendengarkan dan kepuasan pribadi $(\mathrm{p}<0.05)$, antara durasi mendengarkan dan kepuasan hiburan $(\mathrm{p}<0.01)$ serta antara pemilihan acara siaran dan kepuasan pribadi, kepuasan integrasi dan interaksi sosial dan kepuasan hiburan $(\mathrm{p}<0.05)$.
Tabel 8 Jumlah dan persentase responden berdasarkan kepuasan mendengarkan siaran radio komunitas Jaseng FM tahun 2014

\begin{tabular}{|c|c|c|c|}
\hline No & Jenis motivasi & $\begin{array}{l}\text { Jumlah } \\
\text { (orang) }\end{array}$ & $\begin{array}{c}\text { Persen } \\
(\%)\end{array}$ \\
\hline 1 & $\begin{array}{l}\text { Kepuasan pengawasan } \\
\text { Rendah } \\
\text { Sedang } \\
\text { Tinggi }\end{array}$ & $\begin{array}{r}5 \\
21 \\
4\end{array}$ & $\begin{array}{l}16.67 \\
70.00 \\
13.37\end{array}$ \\
\hline 2 & $\begin{array}{l}\text { Kepuasan pribadi } \\
\text { Rendah } \\
\text { Sedang } \\
\text { Tinggi }\end{array}$ & $\begin{array}{r}5 \\
13 \\
12\end{array}$ & $\begin{array}{l}16.67 \\
43.33 \\
40.00\end{array}$ \\
\hline 3 & $\begin{array}{l}\text { Kepuasan interaksi sosial } \\
\text { Rendah } \\
\text { Sedang } \\
\text { Tinggi }\end{array}$ & $\begin{array}{r}1 \\
21 \\
8\end{array}$ & $\begin{array}{r}3.33 \\
70.00 \\
26.67\end{array}$ \\
\hline 4 & $\begin{array}{l}\text { Kepuasan hiburan } \\
\text { Rendah } \\
\text { Sedang } \\
\text { Tinggi } \\
\text { Total }\end{array}$ & $\begin{array}{r}6 \\
13 \\
11 \\
30\end{array}$ & $\begin{array}{r}20.00 \\
43.33 \\
36.67 \\
100.00\end{array}$ \\
\hline
\end{tabular}

Tabel 9 menunjukkan hubungan frekuensi mendengarkan dengan kepuasan mendengarkan radio komunitas Jaseng FM. Hubungan nyata frekuensi mendengarkan dengan kepuasan pribadi menunjukkan bahwa semakin sering pendengar mendengarkan radio komunitas dalam satu minggu, maka akan semakin sering pendengar berpartisipasi melalui line telepon, SMS maupun ikut serta dalam proses siaran radio Jaseng FM. Sebagai pendengar radio komunitas Jaseng FM yang berorientasi sebagai pendengar aktif, pendengar akan merasa terpuaskan sehingga kepuasan identitas pribadi yang lebih berhubungan dengan terpaan media komunitas.

Tabel 9 Hasil uji statistik korelasi antara frekuensi mendengarkan dengan kepuasan mendengarkan radio komunitas Jaseng FM di Kecamatan Walantaka tahun 2014

\begin{tabular}{rlcccc}
\hline & & \multicolumn{3}{c}{ Kepuasan medengarkan } \\
\cline { 2 - 5 } No & $\begin{array}{l}\text { Terpaan } \\
\text { media }\end{array}$ & $\begin{array}{c}\text { Kepuasan } \\
\text { pengawasan }\end{array}$ & $\begin{array}{c}\text { Kepu } \\
\text { asan } \\
\text { pribadi }\end{array}$ & $\begin{array}{c}\text { Kepu } \\
\text { asan } \\
\text { sosial }\end{array}$ & $\begin{array}{c}\text { Kepu } \\
\text { asan } \\
\text { hiburan }\end{array}$ \\
\hline 1 & $\begin{array}{l}\text { Frekuensi } \\
\text { mendengar- } \\
\text { kan }\end{array}$ & 0.572 & $0.047^{*}$ & 0.531 & 0.207 \\
& $\begin{array}{l}\text { Durasi } \\
\text { mendengar- } \\
\text { kan }\end{array}$ & 0.728 & 0.129 & 0.087 & $0.003^{* *}$ \\
3 & $\begin{array}{l}\text { Pemilihan } \\
\text { acara siaran }\end{array}$ & 0.821 & $0.030^{*}$ & $0.026^{*}$ & $0.047^{*}$ \\
\hline
\end{tabular}


Semakin lama mendengarkan radio komunitas, maka semakin tinggi kepuasan mendengarkan khususnya kepuasan hiburan. Hal ini dikarenakan setelah mendengarkan radio komunitas Jaseng FM dengan durasi yang lama, pendengar lebih merasakan kepuasan hiburan seperti mengisi waktu luang, bersantai, dan penyaluran emosi para pendengar. Hakim (2010) juga menyatakan bahwa semakin tinggi durasi mendengarkan radio komunitas mengindikasikan tingkat kedekatan dengan radio komunitas dan semakin tinggi terpaan media komunitas, maka semakin tinggi posisi radio komunitas sebagai media massa yang dapat memenuhi kebutuhan pendengar.

Hasil uji statistik tersebut juga menunjukkan bahwa semakin banyak acara yang dipilih oleh pendengar Jaseng FM, maka akan semakin terpuaskan kebutuhan mereka, tidak adanya hubungan antara pemilihan acara dengan kepuasan pengawasan dikarenakan tingginya motivasi informasi pendengar dan kepuasan pengawasan dalam hal mendapatkan informasi yang dirasakan pendengar setelah mendengarkan radio komunitas Jaseng FM.

\section{KESIMPULAN DAN SARAN}

\section{Kesimpulan}

Terdapat beberapa karakteristik demografis yang berhubungan dengan motivasi mendengarkan radio komunitas Jaseng FM, yaitu 1) usia berhubungan nyata dengan motivasi informasi. Semakin tua usia pendengar radio komunitas, maka semakin tinggi motivasi informasinya, namun akan semakin rendah motivasi identitas pribadi, motivasi integrasi dan interaksi sosial dan motivasi hiburannya, dan 2) tingkat pendapatan berhubungan nyata dengan motivasi informasi, motivasi identitas pribadi dan motivasi integrasi dan interaksi sosial.

Kualitas penyiar dan kesesuaian materi siaran radio komunitas Jaseng FM berhubungan nyata dengan durasi penyiaran, tetapi kualitas pemancar tidak berhubungan nyata dengan frekuensi mendengarkan, durasi mendengarkan, dan pemilihan acara siaran radio. Motivasi informasi tidak berhubungan nyata dengan terpaan media karena tingginya motivasi informasi pendengar tidak mempengaruhi seberapa sering dan seberapa lama mereka mendengarkan radio komunitas. Motivasi identitas pribadi berhubungan nyata dengan pemilihan acara siaran dan durasi mendengarkan, sedangkan motivasi integrasi dan interaksi sosial, dan motivasi hiburan berhubungan nyata dengan durasi mendengarkan radio komunitas.

Frekuensi mendengarkan berhubungan nyata dengan kepuasan pribadi, durasi mendengarkan berhubungan nyata dengan kepuasan hiburan, dan pemilihan acara siaran berhubungan dengan kepuasan pribadi, kepuasan interaksi sosial dan kepuasan hiburan.

\section{Saran}

Saran yang dapat diberikan berdasarkan hasil dari penelitian ini adalah bagi kalangan akademisi agar mahasiswa yang berminat mengkaji mengenai penggunaan media, pada penelitian selanjutnya diharapkan dapat mencoba menerapkan model uses dan gratifications tidak lagi hanya melihat pada penggunaan media radio oleh khalayak, tetapi dapat meneliti penggunaan media infomasi lain, seperti surat kabar dan televisi. Bagi pihak radio sebagai radio komunitas agar lebih menyediakan program khusus yang mencerminkan kebudayaan Kota Serang khususnya Kecamatan Walantaka. Radio komunitas Jaseng FM ini juga sudah cukup terbuka terhadap partisipasi masyarakat demi kelancaran program siaran dan radio komunitas. Selain itu, perlu ditingkatkan kerjasama dengan beberapa pihak yang dapat menjadi narasumber demi terselenggaranya diskusi interaktif atau talkshow mengenai masalah-masalah komunitas pendengar baik di Kecamatan Walantaka maupun pendengar radio komunitas lain di Kota Serang.

\section{DAFTAR PUSTAKA}

Ardianto E, Erdinaya L. 2005. Komunikasi Massa Suatu Pengantar. Bandung:Simbiosa Rekatama Media

Baran S, Dennis K. Davis. (2000). Mass Communication Theories: Foundation, Ferment, and Future. $2^{\text {nd }}$ edition. Belmont, CA: Wadsworth.

Chaplin JP. 1995. Kamus LengkapPsikologi. Jakarta (ID): PT. Raja Grafindo Persada.

Effendy OU. 2007. Ilmu, Teori, dan Filsafat Komunikasi. Bandung (ID): PT. Citra Aditya Bakti.

Feryandes F. 2013. Motivasi dan Perilaku Menonton Program AcaraMerajut Asa Trans 7 (Kasus Anggota Gapoktan Rukun Tani Desa Citapen, Kecamatan Ciawi, Kabupaten Bogor). [Skripsi]. Bogor (ID). Institut Pertanian Bogor. 
Haidar. 2011. Perilaku Remaja dalam Mendengarkan Radio Komunitas (Kasus Pendengar BeTe Radio di Kelurahan Tegal Gundil, Kecamatan Bogor Utara, Kota Bogor, Provinsi Jawa Barat). [Skripsi]. Bogor (ID). Institut Pertanian Bogor.

Hakim AF. 2010. Hubungan Karakteristik, Persepsi dan Terpaan Media Komunitas Dengan Kepuasan Pendengar Radio Komunitas Kasus Radio Komunitas Suara Kencana, Kelurahan Kencana, Kecamatan Tanah Sareal Kota Bogor Provinsi Jawa Barat. [Skripsi]. Bogor (ID). Institut Pertanian Bogor.

Hendrawati. 2013. Pemanfaatan Siaran Radio Dalam Memperoleh Informasi Publik (Studi di Provinsi Kalsel, Kalteng dan Sulteng). Jurnal Kebijakan Pembangunan. [internet]. [dikutip tanggal 6 Desember 2013]. 1(2). Dapat diunduh dari: http://pilnas.ristek.go. $\mathrm{id} / \mathrm{ojs} / \mathrm{jkp} /$ index.php/ jurnal/article/view/4

Herawati FA, Listiorini D, Manurung PH. 2005. Motivasi Bermedia dan Manfaat Menggunakan Radio Komunitas. Communique. [internet]. [dikutip tanggal 6 Desember 2013]. 2(1). Dapat diunduh dari: http:/dspace.library.uph. edu:8080/handle/ $123456789 / 527$

Jurriëns E. 2003. Radio Kpomunitas di Indonesia: 'New Brechtian Theatre' di Era Reformasi. Antropologi Indonesia. [internet]. [dikutip tanggal 1 November 2013]. 72. Dapat diunduh dari: http://ejournal.undip.ac.id/ index.php/ interaksi/article/view/4450

Masduki. 2004. Jurnalistik Radio. Yogyakarta (ID). LKIS.

McQuail D. 1987. Teori Komunikasi Massa edisi kedua. Jakarta: Erlangga

McQuail D. 2010. McQuail's Mass Communication Theory, $6^{\text {th }}$ ed. Singapore: SAGE Publications Asia-Pacific Pte Ltd.

Morissan. 2005. Media Penyiaran: Strategi Mengelola Radio dan Televisi. Tangerang : Ramdina Prakarsa.

Mugniesyah SS. 2006. Pendidikan orang dewasa. Bogor (ID): Institut Pertanian Bogor.

Huntemann N. 1999. Corporate Interference: The Commercialization and Concentration Radio Post the 1996 Telecommunications Act. Journal of Communication Inquiry[internet]. [dikutip tanggal 23 Oktober 2013]. 23 (390). Dapat diunduh dari: http://jci.sagepub.com/ content/23/4/ 390.short
Nurmayanti AW. 2011. Hubungan Perilaku Komunikasi dengan Pemahaman Petani terhadap Fungsi Radio Komunitas Petani Trisna Alami Desa Kaliagung Kecamatan Sentolo Kabupaten Kulon Progo Provinsi Yogyakarta. [Skripsi]. Bogor (ID). Institut Pertanian Bogor.

Nurudin. 2007. Pengantar Komunikasi Massa. Jakarta (ID). PT Rajagrafindo Persada.

PatrisiaR. 2011. Efek Pemberitaan Pra Pemilihan Kepala Daerah Kalimantan Tengah. [skripsi]. [internet]. [dikutip tanggal 4 Januari 2014]. Yogyakarta: Universitas Atma Java Yogyakarta. Dapat diunduh dari: http: journal.uajy.ac.id/2360/

Prasetyo MF. 2008. Program acara Lek-Lekan Solo di Solo Radio (Studi Korelasi Antara Motivasi dan Perilaku dengan Kepuasan Mendengar Program Acara Lek-Lekan Solo di Solo Radio Bagi Perkumpulan Pendengar Program Acara Lek-Lekan Solo di Solo Radio/Lek-Lekan Community). [skripsi]. [internet]. [dikutip tanggal 1 Oktober 2013]. Surakarta: Universitas Sebelas Maret. Dapat diunduh dari: http://dglib.uns.ac.id/ pengguna.php?mn=detail\&d_id=7301

Pratiwi AY. 2008. Tingkat Partisipasi Warga dalam Penyelenggaraan Radio Komunitas (Kasus: Radio Komunitas Suara Kencana, Kecamatan Tanah Sareal, Kota Bogor). [Skripsi]. Bogor (ID). Institut Pertanian Bogor.

Rachmiatie A. 2007. Radio Komunitas Eksalasi Demokrasi Komunikasi. Bandung(ID): PT Remaja Posdakarya Offset.

Rakhmat J. 2002. Psikologi Komunikasi. Edisi Revisi. PT.Remaja Rosdakarya. Bandung.

Romli ASM. 2009. Dasar-Dasar Siaran Radio “Basic Announcing”.Bandung (ID). Nuansa Bandung. 260 hal.

Rosalia N. 2012. Faktor-Faktor Penting Daya Tarik Stasiun Radio Bagi Pendengar Radio di Kota Semarang. Jurnal Interaksi. [internet]. [dikutip tanggal 1 Oktober 2013]. 1(1). Dapat diunduh dari: http://ejournal. undip.ac.id/index.php/interaksi/article/view/4 450

Shun CK. 2000. The Emergence, Transformation, and Disintegration of Alternative Radio in Taiwan : From Underground Radio to Community Radio. Journal of Communication Inquiry. [internet]. [dikutip tanggal 27 Oktober 2013]. 24(412). Dapat 
diunduh dari: http://jci.sagepub.com/ content/24/4/412.abstract

Singarimbun M, Effendi S. 2008. Metode Penelitian Survai. Jakarta (ID): Lembaga Penelitian, Pendidikan, dan Penerangan Ekonomi dan Sosial (LP3ES).

Tripambudi S. 2011. Radio Komunitas sebagai Media Alternatif untuk Pemberdayaan Masyarakat. Jurnal Ilmu Komunikasi. [internet]. [dikutip tanggal 24 Oktober 2013]. 9(3). Dapat diunduh dari: http://repository.upnyk.ac.id/2518/

Undang-Undang No. 32 Tahun 2002 tentang Penyiaran [Internet]. [diunduh tanggal 1 Oktober 2013]. Tersedia pada: http://epenyiaran.kominfo.go.id/TempView/UU\%20 No.\%2032\%20Tahun\%202002\%20tentang\% $20 \% 20$ Penyiaran.pdf.

Winnetou T, Setiawan I. 2005. Peranan Radio Komunitas Agro dalam Pelayanan Informasi Pertanian di Desa Pengalengan. Mediator. [internet]. [Dikutip tanggal 6 Desember 2013]. 8(2). Dapat diunduh dari: http://mediator.fikom.unisba.ac.id/index. $\mathrm{php} /$ mediator/article/view/85

Yani AS. 1998. Hubungan beberapa karakteristik dan perilaku komunikasi pemuka-pemuka tani dalam diseminasi teknologi model farm di daerah aliran sungai (DAS) Citanduy, Ciamis, Jawa Barat. [skripsi]. [internet]. [dikutip tanggal 4 Januari 2014]. Bogor: Institut Pertanian Bogor. Dapat diunduh dari: http://agris.fao.org/agris-search/ search. do?recordID=ID9000436 
Putri \& Hadiyanto / JSKPM 1(3): 245-260 